\title{
Do the Key Sectors Depend on Changing the Income Level of Countries?
}

\author{
Burcu Oralhan $^{1} \&$ Eyüp Emre Uluğ ${ }^{2}$ \\ ${ }^{1}$ Department of Business Administration, Nuh Naci Yazgan University, Kayseri, Turkey \\ ${ }^{2}$ Department of Economics, Nuh Naci Yazgan University, Kayseri, Turkey \\ Correspondence: Burcu Oralhan, Department of Business Administration, Nuh Naci Yazgan University, Kayseri, \\ Turkey. E-mail: boralhan@nny.edu.tr
}

Received: November 4, 2020

Accepted: December 23, 2020

Online Published: January 11, 2021

doi:10.5430/rwe.v12n2p37

URL: https://doi.org/10.5430/rwe.v12n2p37

\begin{abstract}
This study aims to identify key sectors in countries showing any class change in level of income and to examine whether there is any relationship between sectors and income classes. Another aim of the study is to identify emerging and disappearing sectors in key sectors during periods when countries' income levels change. In this context, four basic income classes published by the World Bank are examined for 43 countries but class change was identified only in 12 countries between 2000-2014. A statistical difference was determined between the sectors in the classes at Low and Low Middle levels and Upper Middle and High) classes. Among these countries discussed in the 15-year period with 56 sectors examined, some sectors showed feature of being common key sectors, some tendency to be a key sector in recent years and some sectors have lost their key feature before or after the direct income class changes
\end{abstract}

Keywords: input-output model, Leontief, WIOD, income level, world economy

\section{Introduction}

The economy comprises several sectors, and each sector is defined by its total production output. Since sectors are interdependent, the change in one or more sectors or fluctuations in the economy will affect the entire system. InputOutput (IO) analysis is one of the most widely applied quantitative analytical frameworks of techniques in economics (Baumol et al., 2009). Its fundamental purpose is to analyze the interdependence of various industries or sectors in an economy, such as agriculture, manufacturing or services. The input-output analysis framework has been developed on the fundamental studies of Leontief (Leontief, 1936; Leontief et al., 1953; Leontief, 1974). The input/output tables prepared by Leontief were first published in 1919 and 1929 for US interindustry transactions. Since 1936, on the other hand, an increasing number of countries' and regions' input-output tables have been routinely created worldwide (Liu and Martston, 2017). However, with globalization, industrial linkages have now reached beyond national borders. For this reason, it has become more difficult for national-level input-output tables to catch the details of the global industry and value chains (Lui and Martston, 2017).

Systematic introduction and implementation of the input-output model, a simplified general production theory, was carried out by Miller and Blair $(1985,2009)$. Depending on the interdependence of change in policy and external shocks on imports and exports, input-output tables are used to estimate the trade volume between countries or sectors that will affect a country's economy. Input-output tables may be created to accept countries as regions, as well as to consider the interactions of sectors between regions in a country (Tan et al., 2018). The model put forward by Miller and Blair is a useful tool in economic decision-making processes that is used in many countries because it is capable of describing the degree of the interdependencies among various economic sectors and providing estimates of ripple effects associated with structural changes (Tan et al., 2018). Input-output tables reflect cross-sectoral interdependencies containing forward and backward linkages. In other words, they become determinatives of to what extent the growth in one sector contributes to the growth of other sectors (Freytag and Fricke, 2017). Forward and backward linkages were detailed by Jones (1976). Over the past eight decades, the evolution of input-output analysis has been based upon two major pillars: theoretical foundation and data construction. As reflected in the four quarters of the input-output table, the distinction generally made in input-output analysis is between production of goods and services and their uses. In these tables, Quadrant I shows the intermediate transactions, Quadrant II shows the sales 
by the producing industries to final uses, Quadrant III shows the primary (factor) inputs, and Quadrant IV records two equivalent measures of gross domestic product (GDP) (Cheng and Daniels, 2016).

Basically, the input-output model explains the cross-sectoral relationship in a given economy. Assuming that there are two sectors in one country, the $\mathrm{i}$ and $\mathrm{j}$ sectors, the movement from sector $\mathrm{i}$ to sector $\mathrm{j}$ may be defined as "output" from sector $\mathrm{i}$ and "input" to sector $\mathrm{j}$. The same logic may be used to explain the movement from sector $\mathrm{j}$ to sector $\mathrm{i}$. Internal movements (for example, transfer from sector i to sector i) are also accounted for with input-output analysis. While IO analysis reveals the linkages of industries in an economy, it provides useful information on whether a sector is the driving force of economic growth in both developed and developing countries. The first attempt to identify and measure cross-sectoral linkages was made by Hirschman (1958). One year before Hirschman's work was published, Danish economist Rasmussen (1957) defined two linkage criteria: "the strength of dispersion", interpreted as the point of departure, and "the sensitivity of dispersion", interpreted as a measure of forward linkage.

Some of the main topics in the field of IO modeling are identifying, predicting and prioritizing the key sectors in an economy. The term "key sector" describes the sector which has a strong impact on other sectors in the economy (Gorska, 2015). This measurement was determined based on the sum of column elements in the basic sectors technical coefficient matrix A and Leontief inverse L. Cuello et al. (1992) developed these studies to provide more precise information on the economic significance of key industries. Comparison and discussion of input-output methods, on the other hand, were carried out by Drejer (2002). A detailed description of the different approaches adopted to cover up the deficiencies of traditional linkage methods was provided by Miller and Blair (2009). Sonis et al. (2000) developed the multiplier product matrix (MPM) to visualize the economic landscape with backward and forward linkages. In modeling cross-sectoral interactions in the economy and estimating the effects of changes in one part of the economy on others, again, IO analysis is used (Leontief, 1986; Shaik and Tonak, 1994).

In the literature, there are studies which cover one or more countries and/or sectors and in which analysis is carried out using the Leontief input-output method, including the economic conditions in countries. The input-output model is a traditional and effective approach used to measure the direct and indirect effects of industries as per output, added value, household income and employment (DeSalvo, 1994; Hughes, 1997). In the literature, research on input-output analysis has been carried out on different sectors in many different countries. There are studies for the port industry in Ireland (Morrissey and O'Donoghue, 2013), Italy (Danielis and Gregori, 2013), and Spain (Garza-Gil et al., 2017), for the fishing industry in Indonesia (Zuhdi, 2016a, 2016b), and in addition to these, there are studies on industries such as the construction industry (Balaban, 2011; Giang and Pheng, 2011; Lewis, 2009), automotive (Timmer et al., 2015), water (Shi and Zhan, 2015; Llop, 2013), port sectors (Chang et al., 2014), textile (Masum and Inaba, 2018), environment (Wiebe et al., 2019) and tourism (Cai, Leung, and Mak, 2006; Oosterhaven and Fan, 2006). Lewis (2009) suggested that, as an economy develops, the construction industry loses its importance in the economy. In the literature, the construction industry is deemed as one of the main driving forces of the overall economy in terms of its strong intra-industrial linkages. In general, when backward and forward linkages are examined, there are studies stating that the construction sector is among the first four most active sectors (Balaban, 2011; Giang and Pheng, 2011). It is pointed out that the indicators of the forward linkages in the construction sector are relatively fewer than those of the backward linkages (Bon and Pietroforte, 1990; Giang and Pheng, 2011). However, when the focal point is developed countries, as the sector's production multiplier, the pull effect induced by the backward linkage indicators seems relatively weak in comparison to the push effects shown by the forward linkage indicators in the economy (Pietroforte and Gregori, 2003). Nevertheless, in IO studies, in recent years, an increase has been observed in studies on energy consumption and emissions of the sectors. IO Leontief methodology in energy research (or energy IO) has a very important place in energy policy studies worldwide (Su and Ang, 2015; Cui et al., 2015; Wu and Chen, 1990; Mu et al., 2010). Therefore, in formulation and implementation of a sustainable energy policy, it is important to measure the direct and indirect energy required for each individual industry (Limmeechokchai and Suksuntornsiri, 2007; Jain, 2012; Su and Ang, 2015). While Jain (2012) examined the energy consumption of Indian industries, Park and Heo (2007) evaluated the direct and indirect household energy needs in South Korea, and Rosado and Ferrão (2008) examined energy consumption among households in Portugal. In the literature, there are studies carried out in Thailand (Tia et al., 2006), China and Japan (Su and Ang, 2012; Li, 2015; Zhang and Lahr, 2011) and many other countries where the IO model was integrated with energy consumption and emission intensity.

In a study published in 2000 to identify the key sectors in the Chinese economy, the input-output tables created for China in 1987, 1992 and 1997 were utilized. As a result of comparison of the economic structures of the sectors, textile, chemical, metal production and machinery, equipment and electronics were designated as the key sectors (Sonis, Hewings, and Guo, 2000; Guo and Hewings, 2001). A different study proposed a comparative analysis of 
traditional and modern methods. This core of key sectors comprises agriculture, textiles, chemicals, building materials, primary metals, machinery (Andreosso - O'Callaghan, and Yue, 2004), commerce and other services. Another study about the Polish economy also found that the most important input coefficients came from the main diagonal of the input-output matrix for Polish sectors (Gurgul and Majdosz, 2005). The study which was used WIOD tables for the top economic sectors from China, which were led by the "Basic metals and fabricated metals" sector and the "Electrical and optical equipment" sector, and the top most influential economic sectors still belonged to China, which were led by the "Electrical and Optical Equipment" and "Basic metals and fabricated metals" sectors (Tran, Sato and Namatame, 2017). In Croatian Economy key sectors were identified as Manufacture of food products and beverages, Electricity, gas, steam and hot water supply, Construction work, Real estate services, Public administration and defense, Agriculture, hunting and related services, Fishing, operating of fish hatcheries and fish farms and Manufacture of tobacco products. Banka Slovenije (2016), based on the results of their key sector identification study, identified the sectors of Printed matter and recorded media, Recovered secondary raw materials, Sewage and refuse disposal services, sanitation and similar services, Electrical energy, gas, steam and hot water, Construction work, Wholesale trade and commission trade services, except of motor vehicles and motorcycles, Post and telecommunication services.

Although the articles examined for different sectors or countries on the determination of the key sector are included in the literature, an aggregated article examining key sectors and income level change together does not stand out. In the literature, IO studies on the economies of countries can be increased. However, due to the difficult preparation of IO data and the length of the process, not all countries can publish IO data annually. Therefore, the periodic data is decreased availability (Su and Ang, 2012, 2014; Hoekstra and Van Der Bergh, 2003). In developing countries, creation of input-output tables may be subject to greater delays than those seen in developed countries (Tan, 2018). As a result, input-output models provide an understanding of the cross-sectoral condition of the structure in an economy for certain periods.

Economic growth is generally defined as the increase in per capita income in a country over time. In the income classification made by the World Bank, the development status is divided into four separate categories according to the per capita income of the countries: low, low medium, upper medium and high. Therefore, it is expected that changes in the key sector will also be observed in countries that change in the specified categories. When the literature is reviewed, it has been observed that generally the key sectors in a particular country are examined, the key sectors and the environment or energy relationship are evaluated together, or the only key sector in a country is discussed in detail. In this study, different from other studies, the issue is tried to be associated with the sectors of income classification in economic growth. The main purpose of the study is to reveal what kind of change is experienced in key sectors in a country with a changing income class. Another aim of the study is to determine how the changes in key sectors differ between countries in a country with a changing income class. This study examines whether there are differences in key sectors in terms of economy periods of income class change. There are some limitations in terms of time and space in the study. Since the most up-to-date version of the input-output data set prepared by WIOD temporarily covers the period 2000-2014, only the mentioned period could be examined. There are 43 countries in the WIOD data set within the specified period range. Considering the income class change created by the World Bank for the purpose of the study, 12 countries with a change in income class in the 2000-2014 period were identified. In accordance with this situation, only the countries of China, Croatia, Hungary, India, Indonesia, Latvia, Lithuania, Poland, Romania, Russian Federation, Slovak Republic and Turkey were examined and a spatial limitation was made.

In this context, the study consists of three parts where the first section comprises the introduction, aim and scope of the study, as well as a review of the literature. In the second section, methodologies for I-O analysis are explained. In the third section, detailed data are utilized to evaluate sectors for countries and share the Leontief analysis results of countries' key sectors. Finally, the last section provides the conclusion and discussion of the study.

\section{Data and Methods}

In this study, Leontief Input-Output analysis was used to determine the key sectors of countries whose income class varies within the specified time limits. The first historic breakthrough was made by a Russian-born US economist, Wassily W. Leontief (1906-1999), in the late 1930s, for which he received the Nobel Prize in Economic Science in 1973 (Miller and Blair, 2009). The methodology adopted in the study was based on the input-output model developed by Leontief (1951). An input-output table is extremely effective in analyzing the behavior of each industry. The input-output model describes the quantity of products produced by each sector and consumed by each sector. An input may be goods consumed by a sector, while an output is the production of the same sector. IO models follow the 
product's linkages in the process from the raw material stage to the sale of goods. This way, they make it possible to predict the economic effects of any changes in the economy based on cross-sectoral transactions (Rinaldi et al., 2001). The IO model enables analyzing an interdependent economic system in which an industry sector can directly or indirectly affect itself or a different sector.

The terms are named as follows: $(\mathrm{X})$, total output of the economy; " $\mathrm{X}_{\mathrm{i}}$ ", production quantity of the sector i.; " $\mathrm{X}_{\mathrm{ij}}$ ", output quantity given by sector $\mathrm{i}$ to sector $\mathrm{j}$ (intermediate consumption). This is the result of the total and final demand of production for intermediate consumption. Total production of the economy $(\mathrm{X})$, at the same time, shows to what extent sector $\mathrm{j}$ uses the products produced by sector $\mathrm{i}$ in the total production and the percentage of inputs of sector $\mathrm{i}$ to sector $\mathrm{j}$ in relation to the total production of sector $\mathrm{j}$ (Leontief, 1986).

$$
a_{i j}=\frac{x_{i j}}{x_{j}}
$$

Moreover, the technical coefficient aij is the ratio of $X_{\mathrm{ij}}$ (the value the input given by a sector takes to produce its own output) to $X_{j}$ (the production quantity of that sector). This ratio shows the amount of i goods required to produce a unit $\mathrm{j}$ good. These coefficients are named as the direct input coefficients, or since they reflect the technology of the economy at a certain moment, they are also called the technology coefficients or structural coefficients (Miller and Blair, 2009). In this case, the total output is the sum of the intermediate process and the final demand.

$$
\begin{gathered}
X_{\mathrm{i}}=\sum_{\mathrm{j}} \mathrm{a}_{\mathrm{ij}} \mathrm{X}_{\mathrm{j}}+\mathrm{Y}_{\mathrm{i} 0} \\
\mathrm{X}=\mathrm{AX}+\mathrm{Y}_{0}
\end{gathered}
$$

Here, A refers to the input coefficients matrix, and Y0 refers to the external final demand vector. By solving this equation, the equilibrium solution equation expressed as the total output required to meet the final demand can be obtained, which is shown in Eq.4.

$$
\mathrm{X}=(\mathrm{I}-\mathrm{A})^{-1} \mathrm{Y}_{0}
$$

Here, $(\mathrm{I}-\mathrm{A})=\mathrm{L}$, and $(\mathrm{I}-\mathrm{A})^{-1}$ is called the Leontief inverse matrix.

The input-output methodology allows measurement of other indicators of economic significance. The works of Hirschman (1958) and Rasmussen (1956) defined the relationship between sectors and the strength of each sector in the economy to make linkages. As an indicator of how important the output of a sector is for other sectors of the economy, the ratio of the output of this sector directly used as intermediate goods to the total output of the sector gives the effect of direct forward linkage. On the other hand, as an indicator of the magnitude of the demand for one sector's output to other sectors, the ratio of the sum of the intermediate inputs that this sector directly receives from other sectors to the output of the sector gives the direct backward linkage effect of the sector. These two effects are, for sectors $\mathrm{i}$ and $\mathrm{j}$ :

$$
\begin{aligned}
\mathrm{LF}_{\mathrm{i}} & =\left(\sum_{\mathrm{j}} \mathrm{X}_{\mathrm{ij}}\right) / \mathrm{X}_{\mathrm{i}} \\
\mathrm{LB}_{\mathrm{j}} & =\left(\sum_{\mathrm{i}} \mathrm{X}_{\mathrm{ij}}\right) / \mathrm{X}_{\mathrm{j}}
\end{aligned}
$$

The effects of total forward linkage (TLF) and total backward linkage (TLB) are as:

$$
\begin{aligned}
\mathrm{TLF}_{\mathrm{i}} & =\sum_{\mathrm{j}} \mathrm{r}_{\mathrm{ij}} \\
\mathrm{TLB}_{\mathrm{j}} & =\sum_{\mathrm{i}} \mathrm{r}_{\mathrm{ij}}
\end{aligned}
$$

To facilitate comparison of cross-sectoral linkage effects, indexing according to a certain base value can be performed. The most commonly used base value is the sectoral average of linkage effects. Accordingly, the total forward linkage effect index (TFI) and backward linkage effect index (TBI) are given in Eq.7.

$$
\begin{gathered}
\mathrm{TLI}_{\mathrm{i}}=\mathrm{TLF}_{\mathrm{i}} /(1 / \mathrm{N}) \sum_{\mathrm{i}} \mathrm{TLF}_{\mathrm{i}}=\sum_{\mathrm{j}} \mathrm{r}_{\mathrm{ij}} /(1 / \mathrm{N}) \sum_{\mathrm{i}} \sum_{\mathrm{j}} \mathrm{r}_{\mathrm{ij}} \\
\mathrm{TBI}_{\mathrm{J}}=\mathrm{TLB}_{\mathrm{J}} /(1 / \mathrm{N}) \sum_{\mathrm{i}} \mathrm{TLF}_{\mathrm{J}}=\sum_{\mathrm{j}} \mathrm{r}_{\mathrm{ij}} /(1 / \mathrm{N}) \sum_{\mathrm{i}} \sum_{\mathrm{j}} \mathrm{r}_{\mathrm{ij}}
\end{gathered}
$$

The backward and forward measures of dispersion can be calculated by using total linkage indices. These measures are given as follows (Miller and Blair, 2009): 


$$
\begin{aligned}
& D F_{i}=\frac{\left\{(1 / N-1)\left[\sum_{j} r_{i j}-(1 / N) \sum_{j} r_{i j}\right]^{2}\right\}^{1 / 2}}{\left((1 / N) \sum_{j} r_{i j}\right)} \\
& D B_{j}=\frac{\left\{(1 / N-1)\left[\sum_{i} r_{i j}-(1 / N) \sum_{i} r_{i j}\right]^{2}\right\}^{1 / 2}}{\left((1 / N) \sum_{i} r_{i j}\right)}
\end{aligned}
$$

Consequently, Hirschman classified sectors in four categories in terms of their sectoral investment priorities. The categories of this classification may be summarized as follows (Hirschman, 1958):

Category 1: High forward and backward sectoral linkage effects,

Category 2: High backward but low forward sectoral linkage effects,

Category 3: High forward but low backward sectoral linkage effects,

Category 4: Low forward and backward sectoral linkage effects.

Sectoral investment priorities are listed from top to bottom based on category classes. Accordingly, the key sectors are the sectors with the highest investment priority in category 1 . Once resources have been transferred to Category 1 first, the remaining resources should be assigned to the sectors in category 2 . In the second category, sectors with high backward linkages are included. This is because backward linkages create additional demand for the output of upstream sectors, which initially lead to a reverse upturn and higher capacity utilization, as well as a possible upward technological upgrade. The entire impact on the economy depends on the type of sectors in which a sector is linked backwards. Sectors in categories 3 and 4 have the lowest priority (Tregenna, 2008). Sectors with high backward linkages can easily instigate their economy. Therefore, the fact that sectors in category 2 have a higher backward linkage effect than sectors in category 3 makes them appear to be more important.

Therefore, various attempts to harmonize input-output tables for different countries and construct international input-output tables are ongoing. Examples include the Asian IDE-JETRO, the GTAP tables and WIOD. WIOD covers 43 countries, where 56 sectors are classified according to the International Standard Industrial Classification Revision 4 (ISIC Rev. 4) from 2000 to 2014.

\section{Calculation and Results}

This study examined 43 different countries published in WIOD (World Input-Output Database) in the period between 2000 and 2014. However, for the objective of the study, analyses were carried out only for countries whose income level (class) changed during the period of 2000-2014. The study aimed to identify key sectors in countries showing any class change in level of income within the specified process and examine whether there is any relationship between sectors and income classes. Another aim of the study was to identify the emerging and disappearing sectors among key sectors during periods when countries' income levels change. In this context, four basic income classes published by the World Bank were examined for 43 countries, but class change was identified only in 12 countries. The examined countries were as follows: China, Croatia, Hungary, India, Indonesia, Latvia, Lithuania, Poland, Romania, Russian Federation, Slovak Republic and Turkey. Table 1 shows the income level changes of the 12 countries, whose income levels were stated to have changed between 2000 and 2014. 
Table 1. Income level change of countries $2000-2014$

\begin{tabular}{|c|c|c|c|c|c|c|c|c|c|c|c|c|c|c|c|}
\hline Code & 00 & 01 & 02 & 03 & 04 & 05 & 06 & 07 & 08 & 09 & 10 & 11 & 12 & 13 & 14 \\
\hline CHN & LM & LM & LM & LM & LM & LM & LM & LM & LM & LM & UM & UM & UM & UM & UM \\
\hline HRV & UM & UM & UM & UM & UM & UM & UM & UM & $\mathrm{H}$ & $\mathrm{H}$ & $\mathrm{H}$ & $\mathrm{H}$ & $\mathrm{H}$ & $\mathrm{H}$ & $\mathrm{H}$ \\
\hline HUN & UM & UM & UM & UM & UM & UM & UM & $\mathrm{H}$ & $\mathrm{H}$ & $\mathrm{H}$ & $\mathrm{H}$ & $\mathrm{H}$ & UM & UM & $\mathrm{H}$ \\
\hline IND & L & L & L & L & $\mathrm{L}$ & L & L & LM & LM & LM & LM & LM & LM & LM & LM \\
\hline IDN & $\mathrm{L}$ & L & $\mathrm{L}$ & LM & LM & LM & LM & LM & LM & LM & LM & LM & LM & LM & LM \\
\hline LVA & LM & UM & UM & UM & UM & UM & UM & UM & UM & $\mathrm{H}$ & UM & UM & $\mathrm{H}$ & $\mathrm{H}$ & $\mathrm{H}$ \\
\hline LTU & LM & UM & UM & UM & UM & UM & UM & UM & UM & UM & UM & UM & $\mathrm{H}$ & $\mathrm{H}$ & $\mathrm{H}$ \\
\hline POL & UM & UM & UM & UM & UM & UM & UM & UM & UM & $\mathrm{H}$ & $\mathrm{H}$ & $\mathrm{H}$ & $\mathrm{H}$ & $\mathrm{H}$ & $\mathrm{H}$ \\
\hline ROU & LM & LM & LM & LM & LM & UM & UM & UM & UM & UM & UM & UM & UM & UM & UM \\
\hline RUS & LM & LM & LM & LM & UM & UM & UM & UM & UM & UM & UM & UM & $\mathrm{H}$ & $\mathrm{H}$ & $\mathrm{H}$ \\
\hline SVK & UM & UM & UM & UM & UM & UM & UM & $\mathrm{H}$ & $\mathrm{H}$ & $\mathrm{H}$ & $\mathrm{H}$ & $\mathrm{H}$ & $\mathrm{H}$ & $\mathrm{H}$ & $\mathrm{H}$ \\
\hline TUR & UM & LM & LM & LM & UM & UM & UM & UM & UM & UM & UM & UM & UM & UM & UM \\
\hline
\end{tabular}

Source: World Bank, country classifications by income level.

When the relationship between sectors and income class groups was examined statistically by chi-squared analysis, it was found that there was a significant relationship $\left(\mathrm{p}<0.001 ; \chi^{2}: 505.846\right)$. It was determined with Levene's Test statistics that the variances of the data set were not homogeneous $(\mathrm{p}<0.001)$. As a result of the Kruskal-Wallis analysis, a statistically significant difference was determined between the income classes in terms of the sector groups ( $\left.\mathrm{p}<0.001 ; \chi^{2}=61.190\right)$. The groups causing this difference were analyzed by Tamhane's test. In other words, it was observed that there was a difference between the sectors in the classes on the $\mathrm{L}$ and LM levels and UM and $\mathrm{H}$ classes $(\mathrm{p}<0.001)$.

Within the scope of the study, Leontief input-output analysis was conducted to cover 56 sectors for the 12 countries whose income level varied in the period of 2000-2014. According to the Hirschman classification, the sectors whose forward and backward linkages were higher than 1 were deemed as the key sectors. In the period of 2000 - 2014, a total of 42 sectors emerged as the key sectors for the determined countries. Table 2 shows how many times the specified sector appeared in the country as a key sector within the 15-year period that was examined. Accordingly, it was observed that the top ten Electricity, gas, steam and air conditioning supply, Manufacture of food products, beverages and tobacco products, Land transport and transport via pipelines, Manufacture of chemicals and chemical products, Manufacture of paper and paper products, Warehousing and support activities for transportation, Administrative and support service activities, Manufacture of basic metals, Wholesale trade, except of motor vehicles and motorcycles, Crop and animal production, hunting and related service activities sectors were the most key sectors. The least common 5 sectors were, on the other hand, the Public administration and defense, compulsory social security, Manufacture of furniture, other manufacturing, Repair and installation of machinery and equipment, Forestry and logging, Activities auxiliary to financial services and insurance activities sectors. In other words, within the 15-year period that was examined, the Electricity, gas, steam and air conditioning supply sector emerged as a key sector in all countries at least twice. Besides, it was able to remain as a key sector in 10 countries for more than 11 years. Likewise, the Manufacture of food products, beverages and tobacco products sector has remained as a key sector for more than 14 years in nine countries. Similar comments could be made for other sectors and countries. 
Table 2. Distribution of key sectors by country $2000-2014$

\begin{tabular}{|c|c|c|c|c|c|c|c|c|c|c|c|c|c|}
\hline Sec Cod & CHN & $H R V$ & HUN & $I D N$ & $I N D$ & $L T U$ & $L V A$ & POL & ROU & $R U S$ & $S V K$ & TUR & TOTAL \\
\hline D35 & 15 & 11 & 7 & 15 & 15 & 13 & 15 & 2 & 11 & 15 & 15 & 15 & 149 \\
\hline $\mathrm{C} 10-\mathrm{C} 12$ & 15 & 1 & 15 & 15 & 14 & & 15 & 15 & 15 & 5 & 15 & 15 & 140 \\
\hline H49 & & & 9 & 15 & 15 & 9 & 14 & 11 & 4 & 15 & 14 & 14 & 120 \\
\hline C20 & 15 & & 4 & 15 & 15 & 2 & 15 & 3 & & 15 & 15 & 15 & 114 \\
\hline C17 & 15 & & 5 & 15 & 15 & & 15 & 10 & & 6 & 15 & 15 & 111 \\
\hline H52 & & 8 & 5 & & & 10 & 15 & 15 & 10 & 11 & 15 & 15 & 104 \\
\hline $\mathbf{N}$ & & 14 & & 1 & & 10 & 13 & 13 & 12 & 15 & 13 & 13 & 104 \\
\hline C24 & 15 & & & 9 & 15 & & 9 & 2 & 7 & 15 & 9 & 9 & 90 \\
\hline G46 & 1 & 15 & 15 & & & 11 & 6 & 12 & 5 & 11 & 6 & 6 & 88 \\
\hline A01 & & 15 & 15 & & & 7 & & 15 & 15 & 15 & & & 82 \\
\hline $\mathbf{F}$ & & 15 & 3 & 6 & 15 & 15 & & 15 & 12 & & & & 81 \\
\hline $\mathrm{C} 25$ & 14 & 10 & 2 & 3 & 15 & 9 & 2 & 13 & 6 & & 2 & 2 & 78 \\
\hline C13-C15 & 15 & & & & 13 & & 15 & & & & 15 & 15 & 73 \\
\hline C22 & 15 & & & 3 & 15 & & 9 & 13 & & & 9 & 9 & 73 \\
\hline J61 & & 10 & & & & & 14 & 6 & & 15 & 14 & 14 & 73 \\
\hline C19 & 15 & & 1 & 6 & 6 & & 6 & 5 & 4 & 15 & 6 & 6 & 70 \\
\hline G45 & & 9 & & 8 & & 3 & 14 & & & & 14 & 14 & 62 \\
\hline $\mathrm{C} 23$ & 2 & & & & & & 14 & 1 & 8 & 7 & 14 & 14 & 60 \\
\hline C29 & 15 & & & 5 & 8 & 7 & 1 & & & 15 & 1 & 1 & 53 \\
\hline M69_M70 & 13 & 5 & 4 & 1 & & 10 & & 1 & 14 & & & & 48 \\
\hline C26 & 15 & & & & 5 & 5 & 3 & & & 11 & 3 & 3 & 45 \\
\hline I & 12 & & & 5 & 15 & & & & 12 & & & & 44 \\
\hline M73 & & & & & & 15 & & 15 & 11 & & & & 41 \\
\hline C28 & 15 & & & 1 & 11 & & & & & 10 & & & 37 \\
\hline B & 4 & & & & & & & & 14 & 15 & & & 33 \\
\hline M71 & & 15 & 2 & & & 11 & & & 3 & & & & 31 \\
\hline C27 & 15 & & & & 15 & & & & & & & & 30 \\
\hline G47 & & 14 & & & & & 2 & & 5 & 3 & 2 & 2 & 28 \\
\hline K64 & & & 11 & & & 11 & 1 & & 2 & & 1 & 1 & 27 \\
\hline $\mathrm{C} 16$ & 15 & & & & & 5 & & & & & & & 20 \\
\hline R_S & & 4 & & 5 & & 2 & & & 7 & & & & 18 \\
\hline $\mathrm{C} 18$ & & & 15 & & & & & & & & & & 15 \\
\hline J59_J60 & & 9 & 3 & & & 3 & & & & & & & 15 \\
\hline 084 & & & & & & & & & & 15 & & & 15 \\
\hline C31_C32 & & & & & 10 & 1 & & & & 3 & & & 14 \\
\hline C33 & & & & & & 10 & & & & & & & 10 \\
\hline A02 & & 1 & 2 & & & 3 & & & & & & & 6 \\
\hline K66 & & & 5 & & & & & & & & & & 5 \\
\hline L68 & & & & 3 & & & & 1 & & 1 & & & 5 \\
\hline H50 & 3 & & & 1 & & & & & & & & & 4 \\
\hline K65 & & & & & & 4 & & & & & & & 4 \\
\hline C30 & & & & & & 2 & & & & & & & 2 \\
\hline TOTAL & 244 & 156 & 123 & 132 & 217 & 178 & 198 & 168 & 177 & 233 & 198 & 198 & 2222 \\
\hline
\end{tabular}

Source: Author's calculations.

When year-based key sectors for countries were analyzed, on the other hand, an increase in the tendency of sectors such as Land transport and transport via pipelines, Warehousing and support activities for transportation, Wholesale trade, except of motor vehicles and motorcycles, Architectural and engineering activities, technical testing and analysis, Retail trade, except of motor vehicles and motorcycles, Financial service activities, except insurance and pension funding to be the key sector in recent years was observed. On the other hand, there was a decrease in the Manufacture of fabricated metal products, except machinery and equipment, Manufacture of rubber and plastic products, Manufacture of coke and refined petroleum products, Wholesale and retail trade and repair of motor vehicles and motorcycles, Manufacture of other non-metallic mineral products, Manufacture of computer, electronic and optical products and Accommodation and food service activities sectors. 
Table 3. Distribution of key sectors based on years 2000-2014

\begin{tabular}{|c|c|c|c|c|c|c|c|c|c|c|c|c|c|c|c|c|}
\hline CODE & 00 & 01 & 02 & $\mathbf{0 3}$ & 04 & 05 & 06 & 07 & 08 & 09 & 10 & 11 & 12 & 13 & 14 & TOTAL \\
\hline D35 & 9 & 8 & 9 & 9 & 10 & 10 & 11 & 9 & 12 & 12 & 11 & 10 & 10 & 10 & 9 & 149 \\
\hline $\mathrm{C} 10-\mathrm{C} 12$ & 11 & 9 & 10 & 10 & 10 & 9 & 9 & 9 & 9 & 9 & 9 & 9 & 9 & 9 & 9 & 140 \\
\hline H49 & 3 & 6 & 6 & 6 & 7 & 7 & 9 & 9 & 9 & 9 & 9 & 10 & 10 & 10 & 10 & 120 \\
\hline $\mathrm{C20}$ & 9 & 9 & 8 & 8 & 7 & 7 & 7 & 7 & 7 & 7 & 7 & 7 & 8 & 8 & 8 & 114 \\
\hline C17 & 8 & 8 & 8 & 7 & 8 & 8 & 7 & 7 & 7 & 7 & 7 & 7 & 7 & 7 & 8 & 111 \\
\hline H52 & 5 & 6 & 5 & 6 & 7 & 6 & 7 & 7 & 7 & 8 & 9 & 8 & 6 & 8 & 9 & 104 \\
\hline $\mathbf{N}$ & 2 & 3 & 7 & 8 & 7 & 8 & 8 & 8 & 8 & 7 & 7 & 7 & 8 & 8 & 8 & 104 \\
\hline C24 & 8 & 7 & 7 & 7 & 8 & 7 & 8 & 8 & 5 & 3 & 6 & 4 & 4 & 4 & 4 & 90 \\
\hline G46 & 4 & 3 & 3 & 3 & 5 & 5 & 8 & 5 & 8 & 5 & 6 & 9 & 8 & 8 & 8 & 88 \\
\hline A01 & 6 & 6 & 6 & 5 & 6 & 6 & 6 & 5 & 5 & 5 & 5 & 6 & 5 & 5 & 5 & 82 \\
\hline $\mathbf{F}$ & 5 & 5 & 5 & 5 & 5 & 6 & 5 & 4 & 4 & 6 & 6 & 6 & 6 & 6 & 7 & 81 \\
\hline C25 & 9 & 8 & 7 & 5 & 5 & 5 & 5 & 4 & 4 & 5 & 5 & 4 & 4 & 4 & 4 & 78 \\
\hline C13-C15 & 5 & 4 & 4 & 5 & 5 & 5 & 5 & 5 & 5 & 5 & 5 & 5 & 5 & 5 & 5 & 73 \\
\hline C22 & 6 & 5 & 6 & 6 & 6 & 6 & 6 & 6 & 6 & 4 & 4 & 3 & 3 & 3 & 3 & 73 \\
\hline J61 & 2 & 4 & 4 & 5 & 5 & 5 & 5 & 6 & 5 & 4 & 4 & 6 & 6 & 6 & 6 & 73 \\
\hline C19 & 8 & 8 & 8 & 6 & 6 & 3 & 3 & 3 & 3 & 7 & 3 & 3 & 3 & 3 & 3 & 70 \\
\hline G45 & 2 & 5 & 4 & 4 & 6 & 5 & 6 & 5 & 5 & 4 & 4 & 3 & 3 & 3 & 3 & 62 \\
\hline $\mathrm{C} 23$ & 6 & 6 & 5 & 3 & 4 & 5 & 5 & 6 & 5 & & 3 & 3 & 3 & 3 & 3 & 60 \\
\hline C29 & 7 & 4 & 4 & 4 & 4 & 3 & 3 & 2 & 2 & 3 & 3 & 4 & 4 & 4 & 2 & 53 \\
\hline M69_70 & 2 & 1 & 2 & 3 & 4 & 4 & 5 & 4 & 4 & 3 & 3 & 4 & 3 & 3 & 3 & 48 \\
\hline $\mathrm{C} 2 \overline{6}$ & 3 & 3 & 3 & 3 & 3 & 3 & 3 & 3 & 3 & 4 & 6 & 4 & 1 & 1 & 2 & 45 \\
\hline I & 3 & 3 & 4 & 4 & 4 & 4 & 4 & 3 & 3 & 3 & 2 & 1 & 2 & 2 & 2 & 44 \\
\hline M73 & 2 & 2 & 3 & 3 & 3 & 3 & 3 & 3 & 3 & 3 & 3 & 3 & 3 & 2 & 2 & 41 \\
\hline C28 & 2 & 2 & 2 & 2 & 2 & 2 & 2 & 3 & 3 & 4 & 3 & 3 & 3 & 2 & 2 & 37 \\
\hline B & 2 & 2 & 2 & 2 & 2 & 2 & 3 & 3 & 2 & 3 & 2 & 2 & 2 & 2 & 2 & 33 \\
\hline M71 & 1 & 1 & 1 & 2 & 3 & 2 & 3 & 1 & 2 & 2 & 2 & 2 & 3 & 3 & 3 & 31 \\
\hline C27 & 2 & 2 & 2 & 2 & 2 & 2 & 2 & 2 & 2 & 2 & 2 & 2 & 2 & 2 & 2 & 30 \\
\hline G47 & & 1 & 1 & 1 & 1 & 1 & 2 & 1 & 1 & 1 & 2 & 2 & 2 & 6 & 6 & 28 \\
\hline K64 & 1 & & 1 & 1 & 2 & 1 & 1 & 1 & 3 & 3 & 2 & 2 & 2 & 5 & 2 & 27 \\
\hline C16 & 1 & 1 & 1 & 2 & 2 & 2 & 2 & 2 & 1 & 1 & 1 & 1 & 1 & 1 & 1 & 20 \\
\hline R_S & 1 & 2 & & & & 1 & 1 & 1 & 1 & 1 & 1 & 1 & 2 & 3 & 3 & 18 \\
\hline C18 & 1 & 1 & 1 & 1 & 1 & 1 & 1 & 1 & 1 & 1 & 1 & 1 & 1 & 1 & 1 & 15 \\
\hline J59_J60 & & & & 1 & 1 & 1 & & 1 & 2 & & 1 & 1 & 2 & 3 & 2 & 15 \\
\hline 084 & 1 & 1 & 1 & 1 & 1 & 1 & 1 & 1 & 1 & 1 & 1 & 1 & 1 & 1 & 1 & 15 \\
\hline C31_C32 & 1 & 1 & 1 & & & 1 & 2 & 1 & 1 & 1 & 1 & 1 & 1 & 1 & 1 & 14 \\
\hline$\overline{\mathbf{C 3 3}}$ & & & & & 1 & 1 & 1 & 1 & 1 & 1 & & 1 & 1 & 1 & 1 & 10 \\
\hline A02 & 1 & & & & & & & & & & & & 1 & 2 & 2 & 6 \\
\hline K66 & & 1 & 1 & 1 & 1 & 1 & & & & & & & & & & 5 \\
\hline L68 & & & & & 1 & 1 & 1 & & & & & 1 & & & 1 & 5 \\
\hline H50 & 2 & 1 & 1 & & & & & & & & & & & & & 4 \\
\hline K65 & & & & & & & & 1 & 1 & 1 & 1 & & & & & 4 \\
\hline C30 & & & 1 & 1 & & & & & & & & & & & & 2 \\
\hline TOTAL & 141 & 139 & 144 & 142 & 155 & 150 & 160 & 148 & 151 & 145 & 147 & 147 & 145 & 155 & $\begin{array}{c}15 \\
3\end{array}$ & 2222 \\
\hline
\end{tabular}

Source: Author's calculations.

After 2006, Hungary switched from UM to H (except from 2012 and 2013). When this period was analyzed, it was confirmed that the sector of Activities auxiliary to financial services and insurance activities lost its feature of being a key sector after 2005. Likewise, the Manufacture of paper and paper products and Manufacture of chemicals and chemical products sectors lost their feature of being key sectors after 2003. However, in the period of 2006-2013 (except from 2007) for Electricity, gas, steam and air conditioning supply and in the period of 2004-2014 (expect from 2005) for Financial service activities, except insurance and pension funding and Land transport and transport via pipelines, these sectors gained their feature of being key sectors after 2006. It was seen that the sector of Warehousing and support activities for transportation was a key sector from 2008 to 2010. In 2011, 2012 and 2013, it lost its feature of being a key sector, and then, it was again defined as a key sector in 2014.

It draws attention that there was a rotation to UM again in Hungary in 2012 and 2013. From 2007, India switched from L to LM. Before 2007, after 2005, while the sector of Manufacture of coke and refined petroleum products was 
losing its key sector features, after 2004, the sector of Manufacture of motor vehicles, trailers and semi-trailers lost its feature of being a key sector. Yet, in this period, in 2005 and later on, the sector of Manufacture of furniture and other manufacturing, and in 2007 and later on, the sector of Manufacture of machinery and equipment n.e.c. continuously the feature of being key sector.

During the period of switching from UM to H from 2008 (except from 2013), Croatia's Legal and accounting activities, activities of head offices, management consultancy activities sectors in the period of 2000-2006 (except from 2001-2002), in addition to being key sectors after this period, lost their feature of being key periods. After 2009, the sector of Manufacture of fabricated metal products, except machinery and equipment lost it feature of being a key sector. Within this same period, from 2004, the sector of Electricity, gas, steam and air conditioning supply, and in 2003-2005 and 2008-2014, the sector of Motion picture, video and television program production, sound recording and music publishing activities, programming and broadcasting activities gained the feature of being key sectors. In the periods of $2003-2008$ and $2011-2014$, the Telecommunications sector, and in the periods of $2004-2007$ and 2010 - 2014 (except from 2012), the Warehousing and support activities for transportation sector showed the feature of being key sectors.

From 2003, Indonesia switched from L to LM. In the period of 2002-2006, the Accommodation and food service activities sector, in the period of 200-2008, the sector of Manufacture of basic metals, and in the period of 2000-2003, the Manufacture of fabricated metal products, except machinery and equipment sector showed features of being key sectors, they these periods, they lost these features. Collaterally to 2003, Indonesian income status changed, but there were no sectors that gained the feature of being a key sector. However, in 2009 and later on, it was seen that the sectors of Construction, Manufacture of coke and refined petroleum products, Manufacture of motor vehicles, trailers and semi-trailers and Other service activities showed up as key sectors.

In the period of Lithuania's rising from UM to H, there was no key sector which lost its feature despite continuously being a key sector. Only in the period of 2007-2010, the Insurance, reinsurance and pension funding, except compulsory social security sector, and in the period of 2000-2011, the Manufacture of fabricated metal products, except machinery and equipment and Crop and animal production, hunting and related service activities sectors were key sectors, although not continuously. However, for the relevant sectors, in 2012 and later on, it was observed that the feature did not continue. It may be stated that, from 2012, the sector of Forestry and logging, and from 2013, the sector of Other service activities gained the feature of being key sectors.

Romania switched from LM to UM. In the period of 2000-2008 (except from 2003), the sector of Manufacture of other non-metallic mineral products was a key sector, but after that period, it did not seem to show the feature of being a key sector. In the period of 2000-2009 (except from 2003 and 2004), the sector of other service activities was a key sector, but after that period, it did not seem to show the feature of being a key sector. In the year 2005 when the income degree changed and after that, only the sector of Manufacture of basic metals showed the feature of being a key sector in 2006-2014 (except from 2009 and 2010). Apart from this, the sectors of Architectural and engineering activities, technical testing and analysis, Land transport and transport via pipelines, Manufacture of fabricated metal products, except machinery and equipment, Retail trade, except of motor vehicles and motorcycles and Wholesale trade, except of motor vehicles and motorcycles showed the feature of key sectors in the period of 2010-2014.

As Russia switched from LM to UM in $2004-2011$ and switched from UM to H, it also changed its income degree twice in the period 2000 - 2014. So, it must be analyzed in two different periods which are before and after 2004 and 2012. Therefore, if we analyze the sectors that lost the feature of being key sectors in 2004, after the period of 2000-2004, the Manufacture of food products, beverages and tobacco products sector, and at the end of the period of 2000-2003, the Manufacture of furniture, other manufacturing sector lost their feature as key sectors. For the same period, the sectors that gained key sector features were the Manufacture of other non-metallic mineral products sector in 2005-2008 and the Wholesale trade, except of motor vehicles and motorcycles sector in the period of 2004-2014 continuously.

In the period of $2004-2009$, the Manufacture of paper and paper products sector showed the feature of being a key sector, but after that period, it did not have this feature. When we look at the sectors that lost their feature of being key sectors in the 2012 transition period, until the period of 2003-2012, the sector of Manufacture of machinery and equipment n.e.c. had this feature, and then, it seems it lost this feature. In the same period, the sector of Retail trade, except of motor vehicles and motorcycles showed the feature of being a key sector in 2013 and 2014.

Turkey, in and after 2004, continuously switched from LM to UM. While, in the period of 2000-2007, the sector of Manufacture of basic metals, in the period of 2000-2004, the Manufacture of coke and refined petroleum products sector, and in the period of 2000-2008, the Manufacture of rubber and plastic products sector were key sectors, they 
lost their key sector features. After 2004, when the income bracket changed in Turkey, it was observed that there was no sector that showed key sector features.

2012 was accepted as the year when there was a change in income in Latvia, because there was a transition period to UM in 2000-2011 (except from 2000 and 2009), and after 2012, there was a transition to H. While, in the period of 2000-2010 (except from 2008 and 2009), the sector of Manufacture of basic metals, and in the period of 2009-2011, the Manufacture of computer, electronic and optical products sector were key sectors, they lost their key sector features. In 2013-2014, the Retail trade, except of motor vehicles and motorcycles sector, and in the period of 2001-2014, the Wholesale trade, except of motor vehicles and motorcycles sector gained the feature of being key sectors.

Slovakia switched from UM to H since 2007. While, in the period of 2000-2007, the sector of Manufacture of basic metals, in the period of 2000-2004, the sector of Manufacture of coke and refined petroleum products, and in the period of 2000-2008, the Manufacture of rubber and plastic products sector were key sectors, they lost their key sector features. However, in the period of 2006-2014, although not yet continuous, the Wholesale trade, except of motor vehicles and motorcycles sector showed the feature of being a key sector. Before and after the year 2009, when the income degree changed in Poland, there was no sector that was observed to be gaining or losing the feature of being a key sector.

\section{Discussion and Conclusion}

When the 12 countries were analyzed as intended, outside of Poland, some sectors lost their key features before or after the direct income class changes. Some sectors, on the other hand, were found to turn into key sectors. Nevertheless, it was seen that this situation occurred in some common sectors in some countries and different sectors in others. When this condition was evaluated in general, it may be stated that the hypothesis that it makes some sectors less important and others more important in proportion to economic growth was partially confirmed. When the relationship between sectors and income class groups was analyzed statistically by chi-squared analysis, it was found to be a significant relationship. As a result of the Kruskal-Wallis analysis, a statistically significant difference was determined between the income classes in terms of the sector groups. In other words, it was observed that there was a difference between the sectors in the classes on the L and LM levels and UM and $\mathrm{H}$ classes.

According to the results of the study, it is possible to say that the key sector characteristic of some sectors disappeared in the years when the income class of the countries changed. It was observed that there was no expected change in terms of the key sectors in Poland, only in the period when the income level class changed among the countries that are discussed. In other countries, some sectors lost their key sector characteristics before and/or after the year in which the income class changed, while in some sectors, on the other hand, becoming a key sector was the case. However, in countries that differed equally in terms of income class, there was no change in the key sectors in exactly the same sectors.

On the other hand, in the years when there was a change in income class, in terms of the countries where the same sectors lost their features being key sectors, the Accommodation and food service activities sector lost its feature of being a key sector in China (from LM to UM) and Indonesia (from L to LM). while the Manufacture of coke and refined petroleum products sector in India (from L to LM), in Turkey (from LM to UM) and Slovakia (from UM to $\mathrm{H}$ ); Manufacture of fabricated metal products, except machinery and equipment sector in Croatia (from UM to $\mathrm{H}$ in 2008), Indonesia (from L to LM in 2003), and in Lithuania, although it does not coincide with 2012, the year in which the income class changed.

When a similar assessment was made for those who became key sectors, it was observed that the Electricity, gas, steam and air conditioning supply and Warehousing and support activities for transportation sectors gained the feature of being key sectors in Croatia and Hungary, which experienced the same class change in terms of income (from UM to $\mathrm{H}$ ), and the Land transport and transport via pipelines sector, among the countries experiencing different class changes in terms of income, in Hungary (from UM to H) and Romania (from LM to UM). However, at this point, the period when this sector started to gain the feature of being a key sector in Romania (2010-2014) differed from the transition period from LM to UM (2005). It was seen that the Other service activities sector gained the feature of being a key sector in countries that experienced different class changes in terms of income, i.e. in Indonesia (from L to LM) and in Lithuania (from LM to H). Similarly, Wholesale trade, except of motor vehicles and motorcycles sector in Romania and Russia (from LM to UM) and in Latvia and Slovakia (from UM to H), and Retail trade, except of motor vehicles and motorcycles sector in Romania (from LM to UM) and in Russia and Latvia (from $\mathrm{UM}$ to $\mathrm{H})$. 
As a result, input-output models provide projections for the cross-sectoral flow in an economy for a given period. Since creation of input-output tables in developing countries may be subject to greater delays than those seen in developed countries (Tan, 2018), it is not possible to provide up-to-date continuity in studies to be conducted. For this reason, the latest published data set by WIOD were used in the study.

This study has some limitations in terms of number of countries, sectors and years. The most current version of the input-output tables prepared by WIOD covers the period 2000-2014 and 56 sectors. The entire published period and sectors have been analyzed within the scope of the research. Adhering to the purpose of this study, 12 countries were evaluated. Although 43 countries were published by WIOD in the report, it was determined that only the income level classes of these 12 countries changed between 2000-2014. In the literature, no study examining the differentiation in key sectors based on income level change has been found. For this reason, there is not any study to which comparisons could be made. It is thought that this study will contribute to the literature in this sense. More studies are needed to support this research field. Additionally, the emerging and disappearing key sectors regarding the income level change in the countries are given in detail. This research has significance since some inferences and predictions may be made for the sector trends of the countries whose income levels change. Results of this research are analytically rigorous, empirically testable and flexible enough to address policy-relevant scenarios. This study may provide researchers with predictions about the subject and guide policy makers. For further studies, the relationship between the disappearance or emergence of key sectors can be examined by adding different variables to the model (such as price volume index). This research's data can be analyzed by using latest methods. Moreover, alternative approaches can be used for comparing to countries policy implications. This research provides significant contribution for development strategies on economy researches.

\section{References}

Andreosso O'Callaghan, B., \& Yue, G. (2004). Intersectoral linkages and key sectors in China, 1987-1997. Asian Economic Journal, 18(2), 165-183.

Balaban, O. (2011). İnşaat sektörü neyin lokomotifi?. Birikim, 270, 19-26.

Baumol, W. J., \& ten Raa, T. (2009). Wassily Leontief: in appreciation. Eur. J. hist. Econ, 16(3), 511-522.

Bon, R., \& Pietroforte, R. (1990). Historical comparison of construction sector in the US, Japan, Italy and Finland using input-output tables. Construction Management and Economics, 8(3), 233-247.

Botrić, V. (2013). Identifying key sectors in croatian economy based on input-output tables. Radni materijali EIZ-a, (2), 5-24.

Cai, J., Leung, P., \& Mak, J. (2006). Tourism's forward and backward linkages. Journal of Travel Research, 45(1), 36-52.

Chang, Y. T., Shin, S. H., \& Lee, P. T. W. (2014). Economic impact of port sectors on South African economy: An input-output analysis. Transport Policy, 35, 333-340.

Cheng, D., \& Daniels, P. W. (2016). Input-output analysis. International Encyclopedia of Geography, 1-8.

Cuello, F. A., Mansouri, F., \& Hewings, G. J. D. (1992). The identification of structure at the sectoral level: a reformulation of the hirschman-rasmussen key sector indices. Economic Systems Research, 4(4), 285-296.

Cui, L.-B., Peng, P., \& Zhu, L. (2015). Embodied energy, export policy adjustment and China's sustainable development, A multi-regional input-output analysis. Energy, 82, 457-467.

Danielis, R., \& Gregori, T. (2013). An input-output-based methodology to estimate the economic role of a port: the case of the port system of the Friuli Venezia Giulia Region, Italy. Maritime Econonmics \& Logististics, 15(2), $222-255$.

DeSalvo, J. S. (1994). Measuring the direct impacts of a port. Transport. J. 33(4), 33-42.

Drejer I. (2002). Input-output based measures of interindustry linkages revisited - A survey and discussion. CEBR Working Paper 2002-3.

Freytag, A., \& Fricke, S. (2017). Sectoral linkages of financial services as channels of economic development-An input-output analysis of the Nigerian and Kenyan economies. Review of Development Finance, 7(1), 36-44.

Garza-Gil, M. D., Surís-Regueiro, J. C., \& Varela-Lafuente, M. M. (2017). Using input-output methods to assess the effects of fishing and aquaculture on a regional economy: The case of Galicia, Spain. Marine Policy, 85, 48-53.

Gersak, U., \& Muhaj D. (2016). Surveys and analyses: Inter-sectoral production linkages in Slovenia: An 
Input-output analysis. Banka Slonevije, Bank of Slovenia Eurosystem, Surveys and Analyses/Prikazi in Analyse, 1-19.

Giang, D. T. H., \& Pheng, L. S. (2011). Role of construction in economic development: Review of key concepts in the past 40 years. Habitat International, 35, 118-125.

Górska, R. (2015). Backward and forward linkages based on an input-output analysis-comparative study of Poland and selected European countries. Institute of Econometrics Warsaw School of Economics (SGH), Applied Economic Papers, 30-50.

Guo, D., \& Hewings, G. J. (2001). Comparative analysis of China's economic structures between 1987 and 1997: an input-output prospective. Discussion Papers REAL, 1-21.

Gurgul, H., \& Majdosz, P. (2005). Key sector analysis: A case of the transited Polish Economy. Managing Global Transitions, 3(1), 95-111.

Hirschman, A. O. (1958). The strategy of economic development. New Haven: Yale University Press.

Hoekstra, R., \& Van der Bergh, J. C. J. (2003). Comparing structural and index decomposition analysis. Energy Economics, 25(1), 39-64.

Hughes, W. R. (1997). A comparison of economic impacts with the use of economic base and input-output methodologies. Environment and Planing A, 29, 673-684.

Jain, S. (2012). An input-output analysis to estimate embodied energy of goods. International Journal of Scientific and Research Publications, 11(2), 1-12.

Jones, L. P. (1976). The measurement of Hirschmanian linkages. The Quarterly Journal of Economics, 90(2), 323-333.

Leontief, W. (1936). Quantitative input-output relations in the economic system of the United States. Review of Economics and Statistics, 18, 105-125.

Leontief, W. (1974). Structure of the world economy. American Economic Review, 64, 823-834.

Leontief, W. (Ed.). (1986). Input-output economics. Oxford University Press.

Leontief, W., Chenery H. B., Clark, P. G., Duesenberry, J. S., Ferguson, A. R., Grosse, A. P., Grosse, R. N., ... Kisten H. (1953). Studies in the structure of the American Economy. New York, Oxford University Press.

Lewis, T. M. (2009). Quantifying the GDP-construction relationship. Economics for the Modern Built Environment, 34-59.

Li, X. (2015). Driving forces of China's energy and emission growths between 2007 and 2010: a structural decomposition analysis. Oxford Institute for Energy Studies (OIES) Paper: EV 62.

Limmeechokchai, B., \& Suksuntornsiri, P. (2007). Embedded energy and total greenhouse gas emissions in final consumptions within Thailand. Renewable and Sustainable Energy Reviews, 11(2), 259-281.

Liu, W., \& Marston, R. (2017). International encyclopedia of geography: People, the Earth, Environment and Technology. 15 Volume Set.Wiley.

Llop, M. (2013). Water reallocation in the input-output model. Ecological Economics, 86, 21-27.

Masum, M., \& Inaba, K. (2018). A role of textile-clothing industry in the economic structure of Bangladesh: An input-output analysis. The Ritsumeikan Economic Review: The Bi-monthly Journal of Ritsumeikan University, 67(3), 270-290.

Miller, R. E., \& Blair, P. D. (1985). Input-output analysis: Foundations and extensions. Prentice-Hall, Englewood Cliffs, New Jersey.

Miller, R. E., \& Blair, P. D. (2009). Input-output analysis: Foundations and extensions. Cambridge University Press, New York.

Morrissey, K., \& O'Donoghue, C. (2013). The potential for an Irish maritime transportation cluster: an input-output analysis. Ocean \& Coastral Management Journal, 71, 305-313.

Mu, T., Xia, Q., \& Kang, C. (2010). Input-output table of electricity demand and its application. Energy, 35(1), 326-331.

Oosterhaven, J., \& Fan, T. (2006). Impact of international tourism on the Chinese Economy. International Journal of 
Tourism Research, 8(5), 347-354.

Park, H. C., \& Heo, E. (2007). The direct and indirect household energy requirements in the Republic of Korea from 1980 to 2000 - an input-output analysis. Energy Policy 35, 2839-2851.

Pietroforte, R., \& Gregori, T. (2003). An input-output analysis of the construction sector in highly developed economies. Construction Management and Economics, 21(3), 319-327.

Rasmussen, P. N. (1957). Studies in inter-sectoral relations. North-Holland, Amsterdam.

Rinaldi, S. M., \& Peerenboom P. J. (2001). Identifying understanding and analyzing critical infrastructure interdependencies. IEEE Control Systems Magazine, 11-25.

Rosado, L., \& Ferrão, P. (2008). Measuring the embodied energy in household goods: application to the Lisbon City. Conference: ConAccount 2008, Prague, pp. 159-181.

Shaik, A., \& Tonak, E. A. (1994). Measuring the wealth of nations: The political economy of national accounts. Columbia University Press, New York.

Shi, C., \& Zhan, J. (2015). An input-output table based analysis on the virtual water by sectors with the five northwest provinces in China. Physics and Chemistry of the Earth, Parts A/B/C, 79, 47-53.

Sonis, M., Hewings, J. D., \& Guo, J. (2000). A new image of classical key sector analysis: minimum information decomposition of the leontief inverse. Economic Systems Research, 12(3), 401-423.

$\mathrm{Su}$, B., \& Ang, B. W. (2012). Structural decomposition analysis applied to energy and emissions: some methodological developments. Energy Economics, 34(1), 177-188.

Su, B., \& Ang, B. W. (2014). Attribution of changes in the generalized fisher index with application to embodied emission studies. Energy 69, 778-786.

Su, B., \& Ang, B. W. (2015). Multiplicative decomposition of aggregate carbon intensity change using input-output analysis. Applied Energy, 154, 13-20.

Tan, R. R., Aviso, K. B., Promentilla, M.A.B., Yu, K. D. S., \& Santos, J. R. (2018). Input-output models for sustainable industrial systems: Implementation using LINGO. Springer, Singapore.

Tia, W., Suksuntornsiri, P., \& Limmeechokchai, B. (2011). Macro-economic assessment of policy on promotion of NGV in Thailand: an energy input-output analysis. Fuel, 2016, 21-29.

Timmer, M. P., Dietzenbacher, E., Los, B., Stehrer, R., \& de Vries, G. J. (2015). An illustrated user guide to the world input-output database: the case of global automotive Production. Review of International Economics, 23(5), 575-605.

Tran, T. K., Sato, H., \& Namatame, A. (2017). Key economic sectors and their transitions: Analysis of world input-output network. In Robustness in Econometrics (pp. 381-399). Springer, Cham.

Tregenna, F. (2008). Sectoral engines of growth in South Africa: An analysis of services and manufacturing (No. 2008.98). Research paper/UNU-WIDER.

Wiebe, K. S., Harsdorff, M., Montt, G., Simas, M. S., \& Wood, R. (2019). A global circular economy scenario in a multi-regional input-output framework. Environmental Science \& Technology, 53(11), 6362-6373.

Wu, R. H., \& Chen, C. Y. (1990). On the application of input-output analysis to energy issues. Energy Economics, 12(1), 71-76.

Zhang, H., Lahr, \& M. L., (2011). China's energy intensity change from 1997 to 2007: a structure decomposition analysis. In Proceedings of IIOA Conference, pp. 1-20.

Zuhdi, U. (2016a). The dynamics of the total output of the fishery sector: the case of Indonesia. Journal of Physics: Conference Series, 710(012039), 1-10.

Zuhdi, U. (2016b). The dynamics of the total output of the Japanese fisheries sector: an analysis using input-output approach. Journal of Physics: Conference Series, 710(012040), 1-10. 


\section{Appendix A}

\section{Sector Kodes and Names to Appendix A}

\begin{tabular}{|c|c|}
\hline Sector Code & Sector Name \\
\hline A01 & Crop and animal production, hunting and related service activities \\
\hline A02 & Forestry and logging \\
\hline B & Mining and quarrying \\
\hline $\mathrm{C} 10-\mathrm{C} 12$ & Manufacture of food products, beverages and tobacco products \\
\hline $\mathrm{C} 13-\mathrm{C} 15$ & Manufacture of textiles, wearing apparel and leather products \\
\hline C16 & $\begin{array}{l}\text { Manufacture of wood and of products of wood and cork, except furniture; manufacture of articles of } \\
\text { straw and plaiting materials }\end{array}$ \\
\hline $\mathrm{C} 17$ & Manufacture of paper and paper products \\
\hline C18 & Printing and reproduction of recorded media \\
\hline C19 & Manufacture of coke and refined petroleum products \\
\hline $\mathrm{C} 20$ & Manufacture of chemicals and chemical products \\
\hline $\mathrm{C} 22$ & Manufacture of rubber and plastic products \\
\hline $\mathrm{C} 23$ & Manufacture of other non-metallic mineral products \\
\hline $\mathrm{C} 24$ & Manufacture of basic metals \\
\hline $\mathrm{C} 25$ & Manufacture of fabricated metal products, except machinery and equipment \\
\hline $\mathrm{C} 26$ & Manufacture of computer, electronic and optical products \\
\hline $\mathrm{C} 27$ & Manufacture of electrical equipment \\
\hline $\mathrm{C} 28$ & Manufacture of machinery and equipment n.e.c. \\
\hline $\mathrm{C} 29$ & Manufacture of motor vehicles, trailers and semi-trailers \\
\hline $\mathrm{C} 30$ & Manufacture of other transport equipment \\
\hline C31_C32 & Manufacture of furniture; other manufacturing \\
\hline $\mathrm{C} 33$ & Repair and installation of machinery and equipment \\
\hline D35 & Electricity, gas, steam and air conditioning supply \\
\hline $\mathrm{F}$ & Construction \\
\hline G45 & Wholesale and retail trade and repair of motor vehicles and motorcycles \\
\hline G46 & Wholesale trade, except of motor vehicles and motorcycles \\
\hline G47 & Retail trade, except of motor vehicles and motorcycles \\
\hline H49 & Land transport and transport via pipelines \\
\hline H50 & Water transport \\
\hline H52 & Warehousing and support activities for transportation \\
\hline I & Accommodation and food service activities \\
\hline J59_J60 & $\begin{array}{l}\text { Motion picture, video and television programme production, sound recording and music publishing } \\
\text { activities; programming and broadcasting activities }\end{array}$ \\
\hline J61 & Telecommunications \\
\hline K64 & Financial service activities, except insurance and pension funding \\
\hline K65 & Insurance, reinsurance and pension funding, except compulsory social security \\
\hline K66 & Activities auxiliary to financial services and insurance activities \\
\hline L68 & Real estate activities \\
\hline M69_M70 & Legal and accounting activities; activities of head offices; management consultancy activities \\
\hline M71 & Architectural and engineering activities; technical testing and analysis \\
\hline M73 & Advertising and market research \\
\hline $\mathrm{N}$ & Administrative and support service activities \\
\hline O84 & Public administration and defence; compulsory social security \\
\hline R_S & Other service activities \\
\hline
\end{tabular}

\section{Copyrights}

Copyright for this article is retained by the author(s), with first publication rights granted to the journal.

This is an open-access article distributed under the terms and conditions of the Creative Commons Attribution license (http://creativecommons.org/licenses/by/4.0/). 